Haya: The Saudi Journal of Life Sciences

Abbreviated Key Title: Haya Saudi J Life Sci ISSN 2415-623X (Print) |ISSN 2415-6221 (Online) Scholars Middle East Publishers, Dubai, United Arab Emirates Journal homepage: https://saudijournals.com/sjls

Original Research Article

\title{
The Scrutinizes of Anatomical Structure Using Fiber Runkle's Ratio and Scanning Electron Microscopy on Matured Gigantochloa levis and G. scortechinii
}

Razak Wahab $^{1 *}$, Mohd Tamizi Mustafa ${ }^{2}$, Mohamad Saiful Sulaiman ${ }^{1}$, Taharah Edin ${ }^{1}$, Nasihah Mokhtar

${ }^{1}$ University College Technology Sarawak (UCTS), 96000 Sibu, Sarawak, Malaysia

${ }^{2}$ Forest Research Institute Malaysia (FRIM), Kuala Lumpur, Malaysia

DOI: $10.36348 / \mathrm{sjls} .2020 . \mathrm{v} 05 \mathrm{i} 02.001$

| Received: 09.02.2020 | Accepted: 17.02.2020 | Published: 28.02.2020

*Corresponding author: Razak Wahab

\section{Abstract}

The correlations of microphotograph structure properties were made via a matured cultivated three-year-old tropical bamboos namely Gigantochloalevis and G. scotechinii. Bamboos were elected and harvested from the plantation plots located at the Forest Research Institute Malaysia in Kepong, Selangor. The studies focused on the vascular bundles and fibres the resided at the internodes and nodes positioned in seven, eight and nine at the outer, middle and inner crosssection of the bamboo culms. Data was collected according to the sizes of the vascular bundle's length, vascular bundles width, fibre length, diameter, lumens diameter, walls thickness and fiber Runkle's ratio between each of the bamboo species. The two bamboo species manifested similar in characteristics but having different sizes in anatomy and microstructure features. The results in the fibre's morphology studies showed that the textures for each species possess different anatomy characteristics and properties in having different lengths, diameters, cell walls thickness and lumen sizes. The size of the vascular bundle is smaller at the outer position and become more prominent at the central locations.

Keywords: Cultivated Gigantochloalevis, G. scotechinii, anatomy, vascular bundles, fibres, ultrastructure features.

Copyright @ 2020: This is an open-access article distributed under the terms of the Creative Commons Attribution license which permits unrestricted use, distribution, and reproduction in any medium for non-commercial use (NonCommercial, or CC-BY-NC) provided the original author and source are credited.

\section{INTRODUCTION}

Bamboo categorized as non-wood forest products are the best possible alternative to replace timber in the future. It took between three to four years for bamboo to mature before harvesting $[1,2]$. Research in products utilization of bamboo in the modern era has recently intensified. Bamboo products are now used in the engineered bioresources products.

Bamboo, considered among the fastestgrowing plant, has been the focus of research and development in recent years. However, the study of cultivated bamboo stands has so far mostly confined to selected species in silviculture and fertilisers application to enhance growth [3]. Properties of bamboo culms such as the anatomical structures and physical characteristics are known to influences on their durability and strength [4-8]. This is supported by Wahab et al., [4] in their studies on the anatomical and physical properties of cultivated Bambusa vulgaris. The information generated on the anatomical properties pf bamboo can be used to determine their possible proper utilisation. Currently, most of the bamboos are used for making traditional products such as handicraft, basketry, and high-value-added products. Gigantochloa species are considered the most popular among the bamboo-based industry in the tropical regions. These bamboos are easy to regenerate. They possess thick culms wall and having a uniform long length between the nodes and internodes. These make them suitable as materials for industrial usage.

This study aims to determining the anatomical and structural properties between bamboo G. levis and G. scotechinii. These properties investigated due to their strong relationship with strength, preservative absorption, distribution and likely pathways for colonization by micro-organisms [9-11].

\section{MATERIALS AND METHODS MATERIALS}

Bamboo culms of cultivated species Gigantachloalevis, G.scortechinii and G.wrayiwere harvested from the forest managed area in the FRIM, Kepong, Selangor, Malaysia. Matured bamboo culms of 3-year-old were selected as they found to be most 
suitable as for industrial uses. These culms with a diameter range from $10-18 \mathrm{~cm}$ in diameter were taken from randomly chosen clumps, depending on species. Each culm was marked and cut at nodes and internodes 7, 8 and 9. End-coating paint was applied to newly cut surfaces of the culms before transported to the laboratory. The applied paint reduces or preventing moisture evaporation and act as barriers in preventing fungal and insect attacks on the bamboo. The total number of the specimen taken was about ten (10) culms per species.

\section{Sample Preparation}

The bamboo culms were segregated according to the species, and further sub-segregated into nodes and internodes pieces. Specimen blocks intended for anatomical investigations were fixed in formalin-acetic acid (FAA) solution and kept in closed bottles. The FAA consists of $90 \%$ ethanol ( $70 \%$ concentration), $4 \%$ glacial acetic acid and 6\% formaldehyde (37-48\% concentration) $[6,12]$. Each culm was consistently cross-cut into samples consisting of position with and without nodes for subsequent respective studies. The sample prepared as followed the previous reported by Sulaiman et al., [13].

\section{Anatomy Assessment}

The technique used by Wahabet al., [4, 5] and Latif and Tamizi [7] applied in measuring and counting in the distribution of the vascular bundles on the bamboo surface at the cross-section. The anatomical characteristic of the three (3) bamboo species with two locations (node and internode) and three (3) positions (outer, middle and inner layer) of the bamboo culm was studied.

\section{Vascular Bundles}

Method of measuring the vascular bundles' distribution and fibre dimensions was also adopted from the technique used by Wahabet al., $[4,5]$ and Latif and Tamizi [7].

\section{Vascular Bundle Size}

The measuring tools of the scanning electron microscope were used in measuring the sizes of the vascular bundles [14].

\section{Determination of Fiber Morphology \\ Bamboo Maceration}

The bamboos were split to size $20 \mathrm{~mm} \times 10$ $\mathrm{mm} \times$ thickness than was cut tangentially and divided into 3 equal sections (inner, middle and outer layer). Each section was split radials into match stick sizes using a sharp knife. Macerates were prepared from match-stick size's bamboo by placing them in a solution containing glacial acetic acid $(\mathrm{M}=60.05 \mathrm{~g} / \mathrm{mol})$ and hydrogen peroxide $(30 \%$ and $\mathrm{M}=34.01 \mathrm{~g} / \mathrm{mol}$ ) at ratio $1: 1$. The bamboos in the solution were heated over a water bath inside a fume chamber for 2-3 hours until it becomes soft and white. One or two drops of sodium hydrogen carbonate crystals were added to neutralize the acid before the mixture was decanted and washed with distilled water. A through shaking of the mixture was done to separate the individual fibers. Safranin was used to colour the extracted fiber to red. One hundred undamaged or unbroken fibres were measured for their length (L), fibre widths (d), lumen diameter (l) and cell wall thickness (w). Quantimeter Image Analyzer equipped with Lecia Microscope and Hipad Digitizer (Quantimet 520, Cambridge Instruments) was used to observe and measured at computer images at $10 \mathrm{x}$ (length), $100 \mathrm{x}$ (diameter) and $100 \mathrm{x}$ (lumen) magnifications. The calculations of felting factor $(\mathrm{L} / \mathrm{d})$, Runkel's ratio $(2 \mathrm{w} / \mathrm{l})$, and coefficient of the suppleness or flexibility ratio (1/d) carried out in accordance to Mustafa et al., [14].

\section{Cell Wall Structure in Electron Microcopy}

The scanning electron microscope (SEM) and transmission electron microscope (TEM) were used to analyse the fine structure of the bamboo cell walls. For SEM analysis, the samples were then selected and cut into a smaller size for the shorter duration of pre vacuum process. The surface section of samples was cut using high speed microtome blade to ensure the smooth surface. The samples went through pre vacuum process on a thin plate before the Aurum coating process took place (about $20 \mathrm{~nm}$ ) to ensure the efficient conductivity for the analysis process. The apparatus for the coating process is called 'sputters coater' Fison SC 515. Scanning analysis was performed using 'Leica Cambridge S - 360', with magnification up to 4000 times. The samples for TEM analysis were dehydrated in an ethanol series and embedded in Spurr resin. For cell wall structure of bamboo fiber, they were chosen according to species and position in bamboo culm and cut into pieces of 2 × 3 blocks. Samples were then dehydrated in an ethanol series and embedded in Spurr resin (Epon), which polymerized for 24 hours at $60^{\circ} \mathrm{C}$. Transverse sections $(1 \mu \mathrm{m})$ were cut from the embedded material, using the Sorvall ultra microtome (MT 5000) and stained with $1 \%$ Toluidine Blue for lignin distribution determination. This gives a high contrast to lignin rich structure such as middle lamellas and cell corners. The section was viewed under the polarized microscope (Nikon YS2-H). Ultra-thin sections $(0.1 \mu \mathrm{m})$ were obtained from embedded samples, stained with $2 \%$ uranyl acetate and lead citrate and finally viewed under TEM (energy filter - Zeiss Libra ${ }^{\circledR} 120$ ).

\section{RESULTS AND DISCUSSION} Vascular Bundle Distribution

The result for the vascular bundle's distribution on the two (2) selected Gigantochloa species are shown in Table-1. The mean number of vascular bundle for $G$. scortechinii was 6.38 bundle/4 $\mathrm{mm}^{2}$ and G. levisat 4.33 bundle/4 $\mathrm{mm}^{2}$. These were in agreement with Wahab et al., [5] and Latif [15] finding in the number of vascular bundles in $G$. scortechinii. The anatomical features within and between culm of different or even the same 
bamboo species may vary as the individual characteristic of the bamboo itself [9, 14-16].

Different number of vascular bundle in the node and the internode sections were observed in the bamboo culm. The distributions of vascular bundles in the internodes were higher than the nodes. The vascular bundles were also observed to be higher in the number and more compacted in the outer layers of the bamboo culm than those in the inner layers. This is acknowledged by other researchers [17, 7, 18]. Li [19] in her studies on a monopodial bamboo $P$. pubescens found that the numbers of vascular bundles were higher compared to the simpodial bamboo species. Hishamet al., [18] studied on the anatomical, physical and chemical properties the characterization of bamboo $G$. scortechiniiat differentages found that the number of vascular bundle's increases from the inner zone towards the outer zone. Similar trend was reported in sympodial bamboo Phyllostachyspubescens [20]. This indicates that bamboo possesses long and small vascular bundle at the outer zone, but short and big inner the inner zone [8].

Table-1: Number of vascular bundle (per $4 \mathrm{~mm}^{2)}$ between $G$. levis and $G$. scortechinii

\begin{tabular}{|c|c|c|c|}
\hline Position & LOcation & G. levis & G. scortechinii \\
\hline & Outer & $7.46( \pm 1.72)$ & $13.24( \pm 1.75)$ \\
\hline Internode & Middle & $3.00( \pm 0.54)$ & $6.44( \pm 1.12)$ \\
\hline & Inner & $2.54( \pm 0.40)$ & $3.50( \pm 0.64)$ \\
\hline & Mean & $4.33( \pm 0.87)$ & $7.73( \pm 1.17)$ \\
\hline & Outer & $5.94( \pm 3.40)$ & $10.55( \pm 1.77)$ \\
\hline Node & Middle & $3.56( \pm 1.03)$ & $5.80( \pm 1.40)$ \\
\hline & Inner & $2.87( \pm 0.88)$ & $2.75( \pm 1.13)$ \\
\hline & Mean & $4.12( \pm 1.77)$ & $6.37( \pm 1.43)$ \\
\hline
\end{tabular}

*values in bracket represent the standard deviation.

\section{Vascular bundle length}

The results on the the measurement of the vascular bundles length is shown in Table-2. The higher mean of vascular bundle length at internodes were $G$. levis $(1171.14 \mu \mathrm{m})$ followed by $G$. scortechinii $(787.19$ $\mu \mathrm{m})$.

The mean average for vascular bundle length at the nodes were $G$. levis $(1193.89 \mu \mathrm{m})$ followed by $G$. scortechinii $(1078.20 \mu \mathrm{m})$. The vascular bundles lengths were longer at the node than the internodes. The mean average of vascular bundle length for outer layer position was $748.54 \mu \mathrm{m}$, middle layer $1013.25 \mu \mathrm{m}$ and for inner layer was $1131.42 \mu \mathrm{m}$. The vascular bundles lengths were longer at the middle than at the outer and inner periphery.

Table-2: Vascular bundle length $(\mu m)$ between $G$. levis and G. scortechinii

\begin{tabular}{|l|l|r|r|}
\hline Position & Location & G.levis & \multicolumn{1}{c|}{ G.scortechinii } \\
\hline & Outer & $928.73( \pm 303.07)$ & $625.77( \pm 232.89)$ \\
\hline Internode & Middle & $1176.49( \pm 144.23)$ & $882.32( \pm 74.07)$ \\
\hline & Inner & $1408.20( \pm 210.11)$ & $853.60( \pm 110.02)$ \\
\hline & Mean & $1171.14( \pm 219.13)$ & $787.19( \pm 138.99)$ \\
\hline Node & Outer & $769.09( \pm 129.79)$ & $785.40( \pm 193.88)$ \\
\hline & Middle & $1387.66( \pm 65.41)$ & $999.55( \pm 157.05)$ \\
\hline & Inner & $1424.92( \pm 99.85)$ & $1449.64( \pm 172.69)$ \\
\hline & Mean & $1193.89( \pm 98.35)$ & $1078.20( \pm 174.54)$ \\
\hline
\end{tabular}

*Values in bracket represent the standard deviation

\section{Vascular Bundle Width}

The results on the measurement of the vascular bundles width is showed in Table 3. The higher mean of vascular bundle width at the internodes were $G$. levis $(798.26 \mu \mathrm{m})$ and $G$. scortechinii $(544.63 \mu \mathrm{m})$. The mean average at different position showed significant difference between the internodes and nodes. The internodes vascular bundle width was $585.42 \mu \mathrm{m}$ and for nodes was $630.70 \mu \mathrm{m}$. The vascular bundles width was observed to be higher at the node. Prove by previous study by Sulaiman et al., [21], the vascular bundle is oval and varies in sizes depending on the location or position as well as species of bamboo. The mean average of vascular bundle width for outer layer position was $467.23 \mu \mathrm{m}$, middle layer $599.76 \mu \mathrm{m}$ and for inner layer was $757.19 \mu \mathrm{m}$. It shows the significant different between the vascular bundles in samples position. Vascular bundle width was widened at the inner and smaller toward the outer periphery position. This is due to the size of vascular bundle which were smaller and compact at the outer layer, compared to the inner layer of bamboo culms. 
Table-3: Average vascular bundle width $(\mu m)$ between G. levis and G. scortechinii.

\begin{tabular}{|c|c|c|c|}
\hline Position & Location & G.levis & G.scortechinii \\
\hline & Outer & $610.61( \pm 129.41)$ & $382.41( \pm 141.22)$ \\
\hline Internode & Middle & $723.01( \pm 93.36)$ & $494.11( \pm 73.87)$ \\
\hline & Inner & $1061.18( \pm 103.56)$ & $627.62( \pm 101.20)$ \\
\hline & Mean & $798.26( \pm 108.78)$ & $501.38( \pm 105.43)$ \\
\hline & Outer & $570.89( \pm 89.88)$ & $478.04( \pm 46.60)$ \\
\hline Node & Middle & $752.93( \pm 76.08)$ & $593.74( \pm 72.24)$ \\
\hline & Inner & $837.48( \pm 73.18)$ & $691.88( \pm 92.30)$ \\
\hline & Mean & $720.43( \pm 79.71)$ & $587.89( \pm 70.38)$ \\
\hline
\end{tabular}

*values in bracket represent the standard deviation

\section{Fiber Morphology \\ Fiber Length}

The results for the fiber lengths study of the various Gigantochloa species are showed in Table 5, Figures 1 and 2. The statistical analysis shows significant different in the fiber length between the bamboo species. The higher length was obtained from the G. levis $(2039.98 \mu \mathrm{m})$ follow by $G$. scortechinii $(1745.27 \mu \mathrm{m})$.

The mean average for internode fiber length was $2074.24 \mu \mathrm{m}$ and for node was $1672.62 \mu \mathrm{m}$. It shows there was significant different between position at internode and node. The fiber length was higher at the internode compare to the node. At the internode, the anatomy structure was constant but at the node it was quite twisted. The anatomical factor, maybe contribute the different of fiber length between two position. The mean of the fibreer length for outer layer position was $1698.52 \mu \mathrm{m}$, middle layer $2060.41 \mu \mathrm{m}$ and for inner layer was $1861.35 \mu \mathrm{m}$. These show that there were significant different in the fiber length at the internodes, nodes and between the cross-sectional position of the bamboo. Similar observations were made at the internodes and nodes, which shows that the fiber possess longer fiber at the middle layer of bamboo. The same trends were also observed for all the three bamboo species in this study. The fiber length shows considerable differences between species as well as variations within one culm [22]. The mean average for fiber length in genera Gigantochloa from this study was $1600-2000 \mu \mathrm{m}$. The result obtained by Hishamet al., [18] studies on G. scotechinii was between 2350 - 2630 $\mu \mathrm{m}$. While Ireana 2009 [25], study on B. blumeana found the length of fiber was around $2900 \mu \mathrm{m}$. B.vulgaris fiber length is 3600 - $4700 \mu \mathrm{m}$ [4], 1940 $2430 \mu \mathrm{m}[15]$.

The fiber length of G. levis and G. scortechinii in this study ranged $1750-2040 \mu \mathrm{m}$ while the fiber from $P$. Pubescens which growth in large areas of China, Japan, Taiwan and Indochina was about 1300 $\mu \mathrm{m}$ length [17]. Liese [17] studied the structure of bamboo in relation to its properties and utilization. He noted that the fibers contribute $60-70 \%$ by weight of the total culm tissue. Certain species generally have shorter fibers, such as Phyllostachys edulis (1.5 mm), Ph. pubescens $(1300 \mu \mathrm{m})$, other longer ones like
Dendrocalamusgiganteus Oxytenantheranigrocilliata membranaceus $(4300 \mu \mathrm{m})$.

$\mu \mathrm{m})$, $\mu \mathrm{m})$

D.

Comparison with the fiber length of the Softwood $(3600 \mu \mathrm{m})$, The fiber length of Gigantochloa $(1600-2000 \mu \mathrm{m})$ genera was clearly shorter, but still longer than hardwood $(1200 \mu \mathrm{m})$. In fact it is longer than the Eucalytusspp which was popular as a source of short fibers pulp for paper industry [23, 24]. The shortfiber pulp using by paper mill in Malaysia was the Eucalytusspp imported from Brazil. The fibers are combined long fibers pulp from the Softwood imported from Canada. There was a great potential that Gigantochloa fibers can be use as a pulp for future in Malaysia.

\section{Fiber Diameter}

Table- 5 shows thefiber diameter obtained from the study. The larger fiber diameter were G. levis (22.67 $\mu \mathrm{m})$ followed by $G$. scortechinii $(17.26 \mu \mathrm{m})$. The fiber diameter at different position showed that the node has larger fiber diameter at $22.04 \mu \mathrm{m}$ and internodes at $18.23 \mu \mathrm{m}$. Significant different existed between the fiber diameter in make at the internodes and nodes. The fiber diameter at different position showed that the outer layer were $18.49 \mu \mathrm{m}$, middle layer $22.36 \mu \mathrm{m}$ and inner layer $19.56 \mu \mathrm{m}$. The fiber diameter of the Gigantochloa genera in this study ranged between 17 $22.8 \mu \mathrm{m}$. The previous studies on the fiber diameter for G. scortechinii were $26 \mu \mathrm{m}$ [18], 23-37 $\mu \mathrm{m}$ [15], while studies on the species of bambusa genera found that; fiber diameter for $B$. blumeana were $12.0 \mu \mathrm{m}$ [25], $B$. vulgaris was 16.9-18.0 $\mu \mathrm{m}$ [4], 20-42 $\mu \mathrm{m}$ [15]. This study found that the fiber diameter were smaller than the previous studies. The diameter of the fiber of this study was $17-22.8 \mu \mathrm{m}$ and is smaller than the Softwood $(35 \mu \mathrm{m})$ and hardwood $(25 \mu \mathrm{m})$. The comparison between the fiber diameter on this study showed that the fiber diameter Gigantochloagenera $(17-22.8 \mu \mathrm{m})$

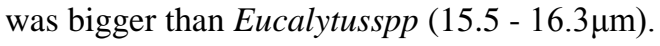

\section{Lumen Diameter}

The results on the measurement of the lumen diameter of the two Gigantochloa species are shown in Table-5. The lumen diameter for $G$. scortechinii and $G$. wrayiwere $8.60 \mu \mathrm{m}$ and $4.75 \mu \mathrm{m}$, respectively. The results obtained in $G$. scortechinii were almost the same 
as obtained by Tamiziet al., [14] and Hisham et al., [18], but smaller than those obtained by Latif [15]. The lumen diameter for Bambusa were $1.6 \mu \mathrm{m}$ for $B$. blumeana [25], 2.3-2.6 $\mu \mathrm{m}$ for B. vulgaris [4]. The lumen diameter for Eucalytusspp was 8.5-9.5 $\mu \mathrm{m}$. The mean average for lumen diameter at different position showed that for the lumen diameter at node was 6.18 $\mu \mathrm{m}$ and for the internodes was $4.43 \mu \mathrm{m}$. The results showed the lumen diameter were larger at the node compare to the internodes. The mean average for lumen diameter at difference position showed that at the outer layer was $5.44 \mu \mathrm{m}$, middle layer was $5.51 \mu \mathrm{m}$ and at the inner layer was $5.96 \mu \mathrm{m}$. The result showed the lumen diameter was largest at the inner and smaller toward the outer layer and it was a significantly difference.

\section{Wall Thickness}

The results on the measurement of the wall thickness between the two bamboo species are shown in Table-5. G. levis with $9.34 \mu \mathrm{m}$ possess thicker wall compare to the $G$. scortechiniiat $4.30 \mu \mathrm{m}$. The wall thickness at different position showed that for the wall thickness at node was $7.02 \mu \mathrm{m}$ and for the internodes was $6.90 \mu \mathrm{m}$. The result showed the wall thickness are thicker at the node as compare to the internodes and it was a significantly difference between this two position. The wall thickness at difference position showed that at the outer layer was $7.03 \mu \mathrm{m}$, middle layer $8.43 \mu \mathrm{m}$ and at the inner layer was $6.80 \mu \mathrm{m}$. The result showed the wall thickness are thicker at the outer and thinner toward the inner layer. From this study the fiber wall thickness for both species ranged 4.3-9.34 $\mu \mathrm{m}$. The fiber wall thickness for $G$. scortechiniiobtained by Hishamet al., [18] was 8-10 $\mu \mathrm{m}$ and Latif [15] was 12.5-30.1 $\mu \mathrm{m}$. The fiber wall thickness of G.wrayi $(9.02$ $\mu \mathrm{m})$, G.brang $(9.34 \mu \mathrm{m})$ was thicker than B. blumeana which was $5.01 \mu \mathrm{m}$ (Ireana, 2009), B. vulgaris which was 7.1-7.6 $\mu \mathrm{m}$ [4], 2.5-13.3 $\mu \mathrm{m}$ [15]. As a comparison, the fiber wall thickness of G.scortechinii almost similar with fiber wall thickness of Eucalytusspp which was 4.3 $\mu \mathrm{m}$ and 3.29-3.86 $\mu \mathrm{m}[26]$, respectively.

\section{Analysis of Variance}

The analysis of variance (ANOVA) for the above studies is shown in Tables 4 and 5. Table- 4 shows the ANOVA on the vascular bundle distribution, vascular bundle length and vascular bundles width between the bamboo species at nodes and internodes. Table 5 shows the ANOVA on the length, fiber diameter, fiber lumen diameter, fiber wall thickness and Runkle's ratio between the bamboo species, position and position.

Table-4: Analysis of variance for anatomical propertiesbetween bamboo species, position \& position

\begin{tabular}{|c|c|c|c|c|}
\hline & & \multicolumn{3}{|c|}{ Anatomical Properties } \\
\hline & & No. Vascular bundle & Vascular bundle length & Vascular bundle Width \\
\hline Species & G. levis & $4.23 \mathrm{c}$ & $1182.51 \mathrm{a}$ & $759.35 \mathrm{a}$ \\
\hline & G. scortechinii & $7.05 \mathrm{a}$ & $932.71 \mathrm{~b}$ & $544.63 \mathrm{c}$ \\
\hline Position & Internode & $6.32 \mathrm{a}$ & $869.87 \mathrm{~b}$ & $585.42 \mathrm{~b}$ \\
\hline & Node & $4.93 \mathrm{~b}$ & $1058.94 \mathrm{a}$ & $630.70 \mathrm{a}$ \\
\hline Location & Outer layer & $8.56 \mathrm{a}$ & $748.54 \mathrm{c}$ & $467.23 \mathrm{c}$ \\
\hline & Middle layer & $4.89 \mathrm{~b}$ & $1013.25 \mathrm{~b}$ & $599.76 \mathrm{~b}$ \\
\hline & Inner layer & $3.42 \mathrm{c}$ & $1131.42 \mathrm{a}$ & $757.19 \mathrm{a}$ \\
\hline
\end{tabular}

Table-5: Analysis of variance for fibre morphology between species, position \& position

\begin{tabular}{|c|c|c|c|c|c|c|}
\hline & & \multicolumn{5}{|c|}{ Fibre Morphology } \\
\hline & & Fibre Length & Fiber Diameter & Lumen Diameter & $\begin{array}{c}\text { Wall } \\
\text { Thickness }\end{array}$ & $\begin{array}{c}\text { Runkle's } \\
\text { Ration }\end{array}$ \\
\hline & & & & & & \\
\hline Species & G. levis & $2039.98 \mathrm{a}$ & $22.67 \mathrm{a}$ & $4.00 \mathrm{c}$ & $9.34 \mathrm{a}$ & $5.32 \mathrm{a}$ \\
\hline & G. scortechinii & $1745.27 \mathrm{c}$ & $17.26 \mathrm{~b}$ & $8.66 \mathrm{a}$ & $4.30 \mathrm{c}$ & $1.35 \mathrm{~d}$ \\
\hline Position & Internode & $2074.24 \mathrm{a}$ & $18.23 \mathrm{~b}$ & $4.43 \mathrm{~b}$ & $6.90 \mathrm{~b}$ & $4.17 \mathrm{a}$ \\
\hline & Node & $1672.62 \mathrm{~b}$ & $22.04 \mathrm{a}$ & $6.18 \mathrm{a}$ & $7.02 \mathrm{a}$ & $3.68 \mathrm{~b}$ \\
\hline Location & Outer layer & $1698.52 \mathrm{c}$ & $18.49 \mathrm{c}$ & $5.44 \mathrm{c}$ & $7.03 \mathrm{~b}$ & $4.04 \mathrm{~b}$ \\
\hline & Middle layer & $2060.41 \mathrm{a}$ & $22.36 \mathrm{a}$ & $5.51 \mathrm{~b}$ & $8.43 \mathrm{a}$ & $4.29 \mathrm{a}$ \\
\hline & Inner layer & $1861.35 \mathrm{~b}$ & $19.56 \mathrm{~b}$ & $5.96 \mathrm{a}$ & $6.80 \mathrm{c}$ & $3.45 \mathrm{c}$ \\
\hline
\end{tabular}

*values followed by the same letter in a column is not significant different at $95 \%$ probability level.

\section{Fiber Runkle's ratio}

The results on the fiber Runkle's ratio between the three Gigantochloa species are shown in Table-6. The higher mean of fiber Runkle's ratio was G. levis 5.32 and the G. scortechinii 1.35 . The mean average of fiber Runkle's ratio for internode was 4.17 and for node was 3.68. It shows there was significant different of the
Fiber Runkle's ratio between position at node and internode of the bamboo. The result showed the fiber Runkle's ratio was bigger at the node as compare to the internodes and it was a significantly difference between this two position. Table 6 showed the value of fiber Runkle's ratio at node and internode. The mean average for fiber Runkle's ratio at difference position showed 
that at the outer layer was 7.03 , middle 8.43 and at the inner layer was 6.80. The result showed that the fiber Runkle's ratio is bigger at the middle and thinner toward the inner and outer layer. It was a significantly difference between this three position.

Table 6 showed the fiber Runkle's ratio value for every species, position and position. Runkle's ratio of fiber in this study was higher than 1.0 for G. wrayi and G. levis. G. scortechinii was the only species has the value of Runkle's ratio less than 1.0. The Runkle's ratio value more than one, this main the fiber properties was hard and difficult to felting during the paper production. The quality of the paper will be gross and poor bonding if Runkle's ratio value more than one. If the Runkel's ratio less than one, it indicates the fiber has a thin fiber wall and easily to felting. The quality of the paper will be better and bonding will be good. This indicates that G.scortechinii could be a source to replace short-fiber pulp that was imported from abroad. Eucalytusspp, the Runkle's ratio is less than 1.0, namely 0.7 and 0.8 [26] was even shorter fiber than G.scortechinii. The Runkle's for hardwood and Softwood was 0.4-0.7 and 0.35 respectively. Kenaf has Runkle's ratio of $0.5-0.7$ to prove they are good fiber felting power. Runkle's ratio for G.scortechinii was lowest than value one, which was 0.97 to prove it can still be used.

Table-6: Runkle's ratio of various Gigantochloa species

\begin{tabular}{|l|l|c|r|}
\hline Sample Position & Location & G.levis & G.scortechinii \\
\hline & Outer & $4.71( \pm 2.80)$ & $2.16( \pm 1.50)$ \\
\hline Internode & Middle & $7.19( \pm 3.09)$ & $1.42( \pm 0.95)$ \\
\hline & Inner & $5.44( \pm 2.09)$ & $0.97( \pm 0.78)$ \\
\hline & Outer & $4.62( \pm 2.09)$ & $1.71( \pm 0.96)$ \\
\hline Node & Middle & $5.29( \pm 2.64)$ & $1.06( \pm 0.64)$ \\
\hline & Inner & $4.64( \pm 2.55)$ & $0.79( \pm 0.57)$ \\
\hline
\end{tabular}

*values in bracket represent the standard deviation.

\section{Ultrastructure Study}

The ultrastructure studies on the Gigantochloa levis and G. scortttechinii are shown in Figures 1 to 4 . Figures $1 \& 2$ shows the ultrastructures of the internodes and nodes focusing at the vascular bundles of the G. levis, and G. scortechinii took using the SEM. Figures-3 and 4 show the images of the bamboo species taken using TEM, focusing on the fibres cells. The cells wall of the fibres indicates that they possess more than two layers, which were $\mathrm{S} 1$, S2, S3 and Sn... All the two bamboo species show clear that they belong to the bamboo is bamboo in class type III [6]. They possess a vascular sheath fibre and one fibre strand. Even though all the cells are similar in shape, but they are however different in sizes in position at internodes and nodes, and position in the bamboo at either the outer, middle or the inner layers. The distribution of the vascular bundles per $\mathrm{mm} 2$, vascular length, and vascular bundle width is shown in Tables 1, 2, 3 and 4. The fibres length, diameter, lumen diameters, wall thickness and the Rumkle's ratio, are given in Tables 5 and 6.

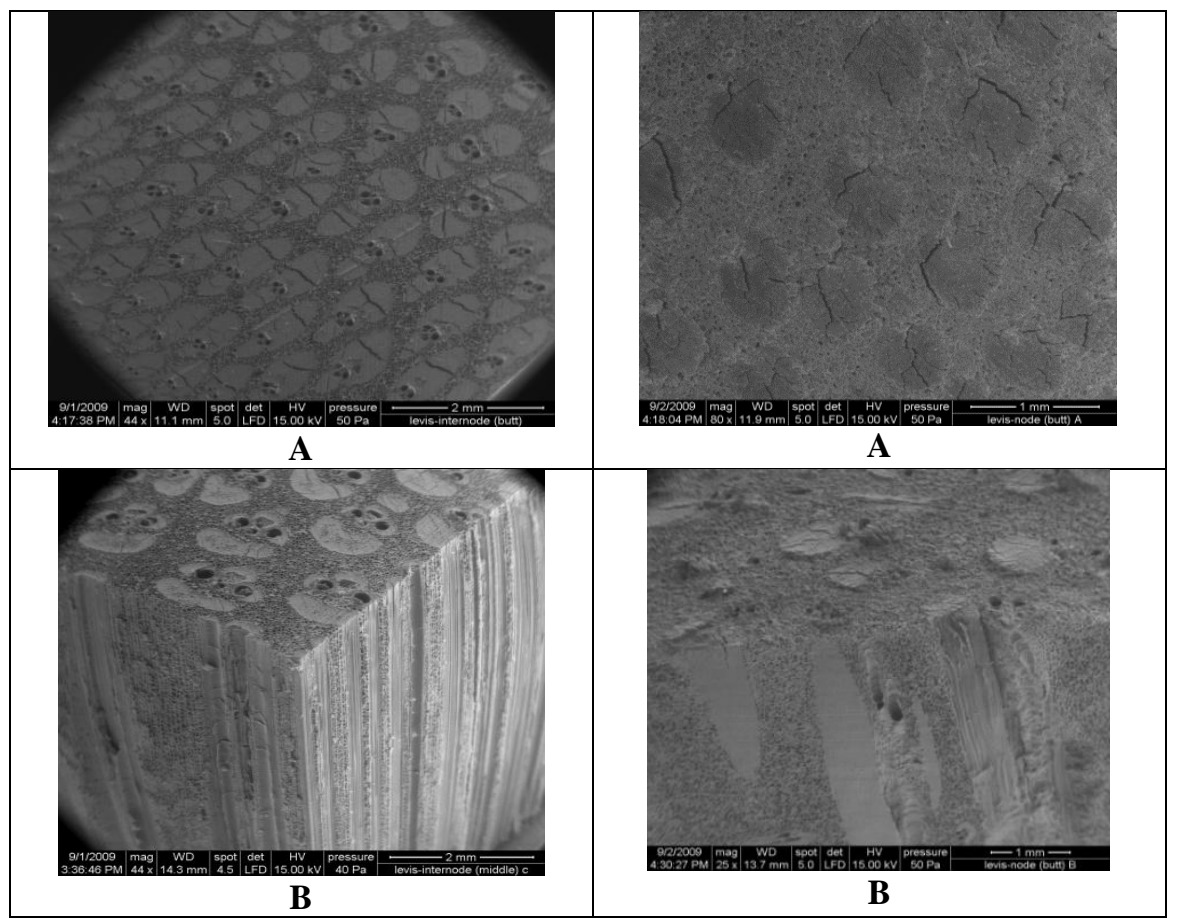




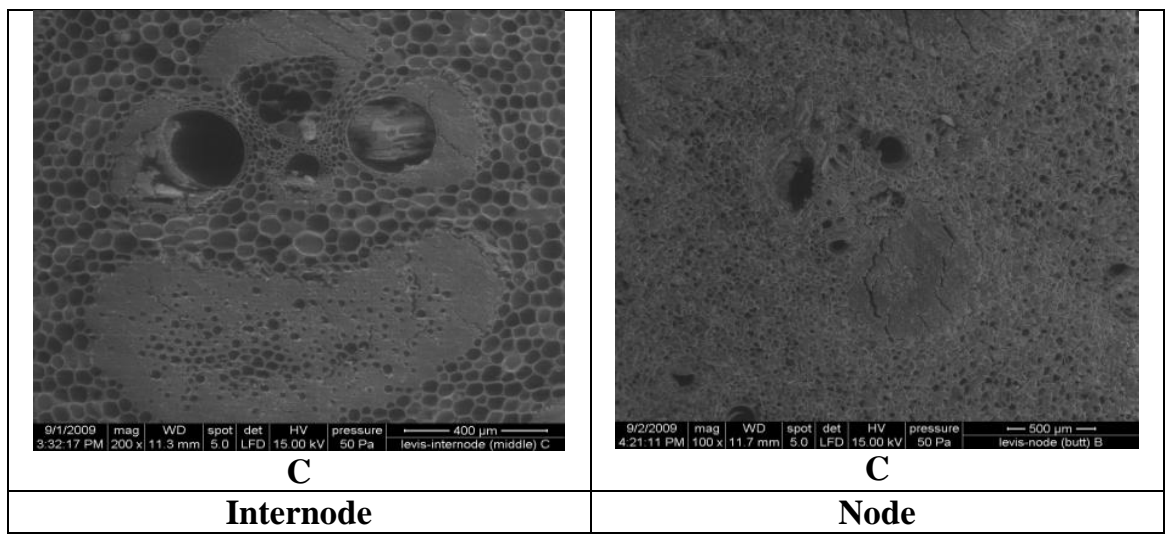

Fig-1: SEM images of the vascular bundles at internodes and nodes of the G. levis

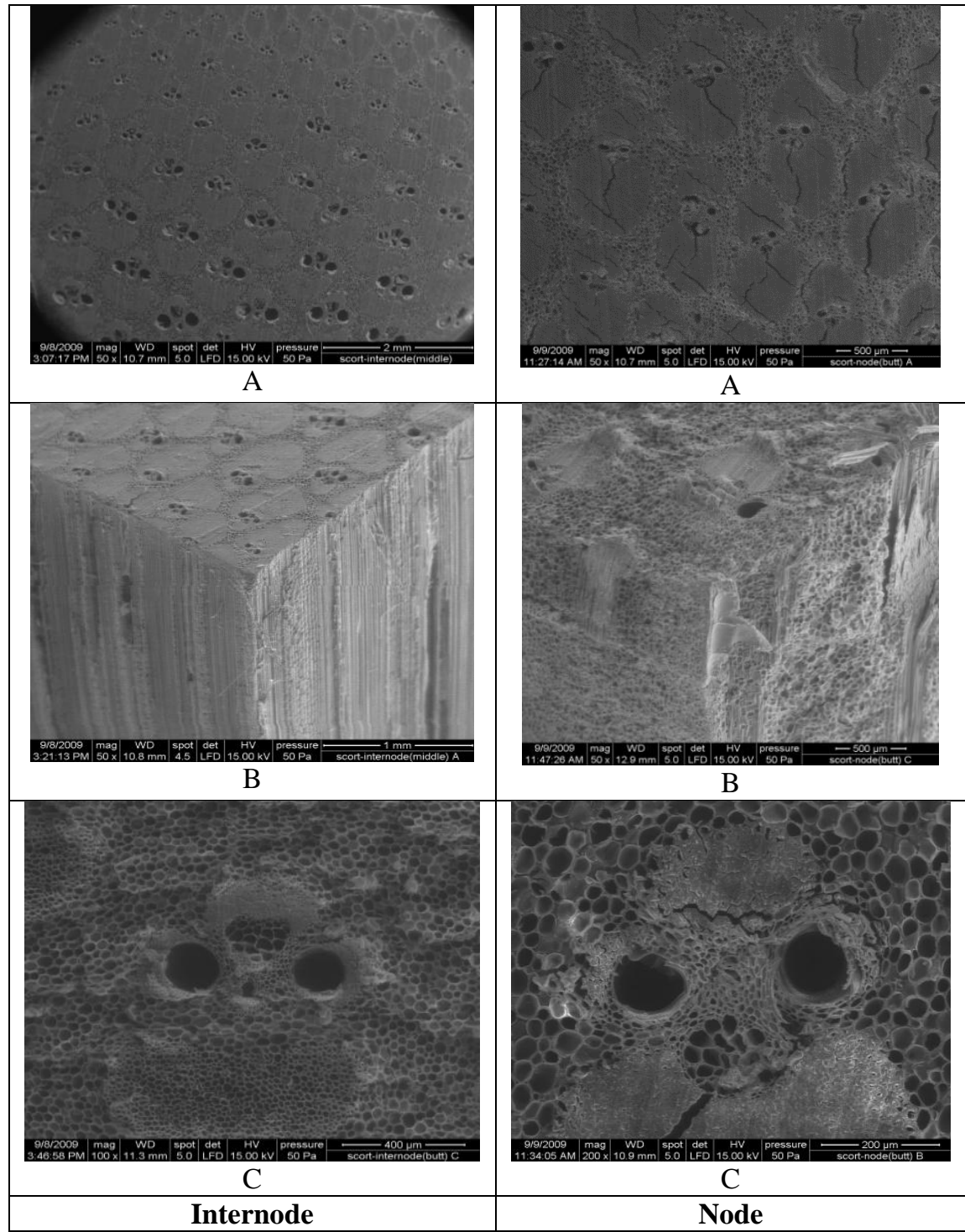

Fig-2: SEM images of the vascular bundles at internodes and nodes of the G. scortechinii

Note: SEM image at the internodes and nodes of G. levis and G. scortechinii. Distribution of vascular bundle (left), isometric view (central) and vascular bundle image (right). 


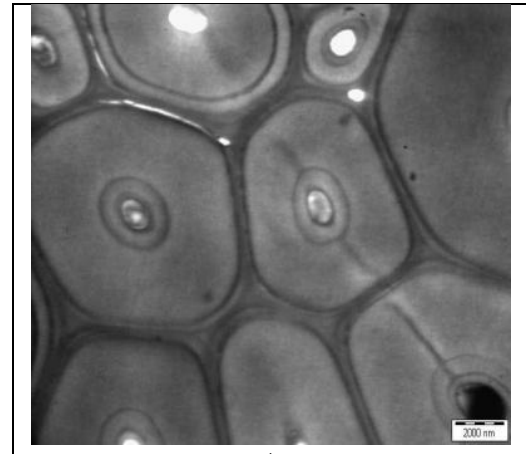

A

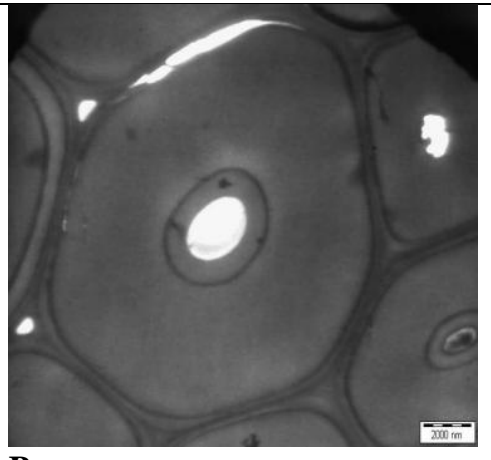

B

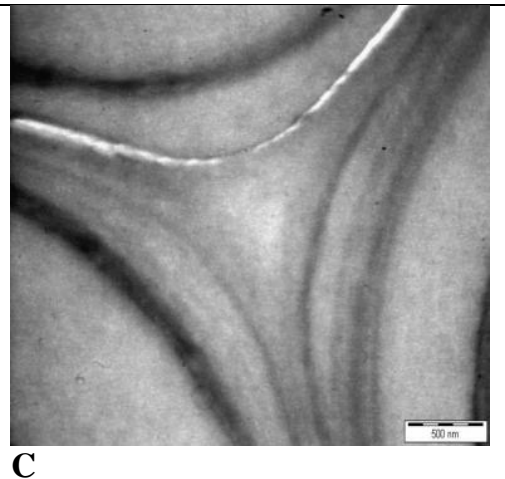

Fig-3: Fibre cells (A, B) and middle lamella (C) at internodes of the G. levis

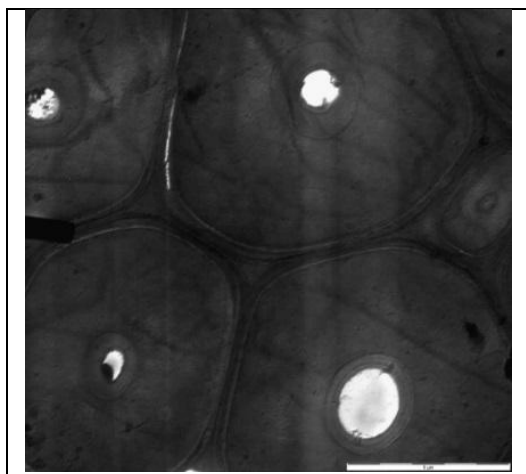

A

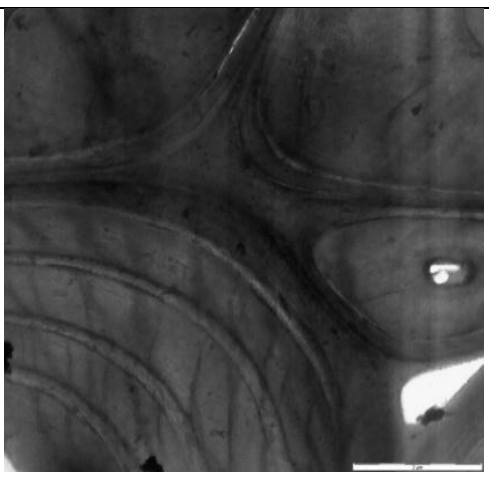

B

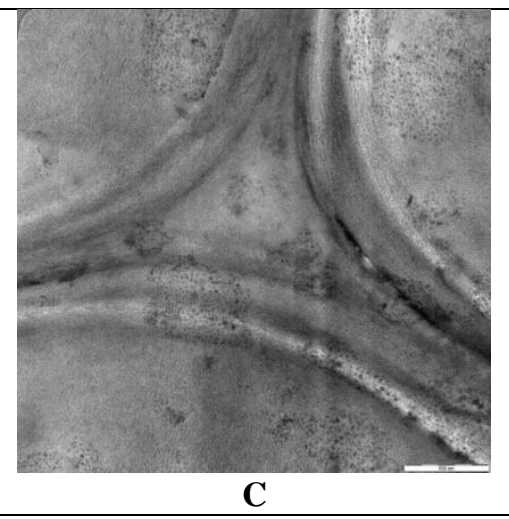

C

Fig-4: Fibre cells (A, B) and middle lamella (C) at internodes of the G. scortechinii

\section{CONCLUSION}

The anatomical structure of the two bamboos varies significantly. The distribution and the size of the vascular bundle are differences between species. The vascular bundle of the two species shows a similar pattern and are classified under Type III consisting of a single vascular sheath fibre and one fibre strand. But, the vascular bundle size was significantly different between position (nodes and internodes) and location (outer, middle and inner layers). Nevertheless, the fibre morphology of each species possesses different measurement in size especially in the length, diameter, lumen diameter and wall thickness. The study identified that there was differences in fiber dimensions on the position between the nodes and internodes, and as well as the location at the outer, middle and inner layer within the same species. The length of the fiber was longer at the internode than the node. The middle layer has the longest fiber length compare to the outer and inner layer. The ultra-structures properties of both $G$. levis and G. scortechinii shows different characteristics than wood. The fiber of both bamboos has a small lumen and thick wall thickness. Wall thickness of wood only has two layers which were $\mathrm{S} 1$ and $\mathrm{S} 2$, while in bamboo the fiber has more than two layers, which were S1, S2, S3 and Sn. Lastly, the G. scortechinii fiber has great potential to be a resource of fiber production. It will be a source to replace short fiber from of hardwood, to combine with soft wood pulp for paper production in the future.

\section{ACKNOWLEDGEMENT}

This study financed by the University College of Technology Sarawak Grants (UCTS/RESEARCH/4/ 2017/01) and (UCTS/RESEARCH/2/2018/01). The authors expressed their gratitude to University College of Technology Sarawak (UCTS) and Forest Research Institute Malaysia (FRIM) for permission in using their laboratory and workshop equipment in the preparation and analysis parts of the study.

\section{REFERENCES}

1. Sulaiman, M. S., Wahab, R., Mhd Ramle, S. F., Ghani, R. S. M., \& Mokhtar, N. (2018). Relationship between Chemical Compositions and Anatomical Structure on the Maturity of 4-YearOld Culms Schizostachyumbrachycladum Kurz. International Journal of Current Research,10(5), 69776-69780.

2. Sulaiman, M. S., Wahab, R., Ghani, R. S. M., Mokhtar, N., Ramle, S. F. M., \& Kahar, S. (2019). Analytical Chemistry of Bambusa vulgaris and Schizostachyumbrachycladumon 2- and 4-Years Old with Transmission Electron Microscopy. Research Journal of Pharmaceutical, Biological and Chemical Sciences. 10(5): 59-68.

3. Azmy, M., Hall, J. B., Othman, S., Wahab, R., \& Rashidah, A. B. K. (2007). Quality management of the bamboo resource and its contribution to environmental conservation in Malaysia. Management of Environmental Quality: $A n$ International Journal. 18(6), 643-656. 
4. Wahab, R., Tamizi, M., Othman, S., Aminuddin, M., Affendy, H., \& Izyan, K. (2010). Anatomical and Physical Properties of Cultivated Two- and Four-year-old Bambusa vulgaris. Sains Malaysiana, 39(4): 571-579.

5. Wahab, R., Mohamad, A., Samsi, H. W., Mohd Yunus, A. A., \& Moktar, J. (2010). Physical characteristics, anatomy and properties of managed Gigantochloascortechinii natural bamboo stands. Journal of Plant Sciences, 5(2), 184-193.

6. Wahab, R. (1998). Effect of selected preservatives on the durability of Gigantochloascortechinii. A $\mathrm{PhD}$ thesis, University of London.

7. Abd. Latif, M., \& Tamizi, M. (1993). Variation in anatomical properties of three Malaysian bamboos from natural stands. Journal Tropical Forest Science, 5(1): 90-96.

8. Liese, W. (1985). Anatomy and properties of bamboo. Recent research on bamboos. Proceedings of the International Bamboo Workshop. Hangzhou, China. 6-14.

9. Wahab, R., Sulaiman, M. S., Ghani, R. S. M., Mokhtar, N., \& Mustafa, M. T. (2019, February). Study on the microstructure properties of a tropical bamboo species by scanning electron and transmission electron microscopes. In AIP Conference Proceedings (Vol. 2068, No. 1, p. 020019). AIP Publishing LLC.

10. Wahab, R., Mahmud, S., \& Hashim, W. S. (2005). Fungal colonization and decay in tropical bamboo species. Journal of Applied Science, 5(5): 897902.

11. Wahab, R., Samsi, H. W., Murphy, R. J. (2002). SEM observation on the decay of bamboo Gigantochloascortechinii exposed in tropical soil. Journal of Tropical Forest Products, 8(2), 168178.

12. Wahab, R., Mustafa, M. T., Norashikin F., Ghani, R. S. M., Sulaiman, M. S., Mokhtar, N., \& Sim, T. K. (2018). The Effects of Anatomy and Physical Properties on the Strength of Cultivated FourYear-Old Bambusa vulgaris. International Journal of Current Research. 10(2), 65439-65448.

13. Sulaiman, M. S., MhdRamle S. F., Geng, B. J., Hashim, R., Sulaiman, O., Ibrahim, N. I., \& Zaudin, N. A. C. (2016). Bambusa vulgaris: Chemical Composition and Cell Wall Structure. European International Journal of Science and Technology, 5(9), 27-39.

14. Mustafa, MT., M., Wahab, R., Mahmud, S., Izyan, K., \& Nurul' Ain, K. (2011). Anatomical properties and microstructures features of four cultivated bamboo Gigantochloa species. Journal of Asian Scientific Research, 1(7): 328-339.

15. Abd Latif, M. (1995). Some selected properties of two Malaysian bamboo species in relation to age, height, site and seasonal variation (Doctoral dissertation, $\mathrm{PhD}$ dissertation, Faculty of Forestry, Universiti Putra, Putra, Malaysia). 282.
16. Soeprayitno, T., Tobing L., \& Widjaja E. A. (1990). Why the sundanese of West Java Prefer Slope-inhabiting Gigantochloapseudoarundinacea to those growing in the valley". In International Workshop on Bamboo held in Cochin, 14-15 Nov. 1988: Proceeding edited by Rao, I. R. R., Gnanaharam, R., \& Sastry, C. B. Peechi: Kerala Forest Research Institute and International Development Research Centre, 215-217.

17. Liese, W. (1992). The structure of bamboo in relation to its properties and utilization. In Zhu, S., Li, W., Zhang, X., \& Wang, Z. ed., Bamboo and its use. Proceedings of the International symposium on Industrial Use of Bamboo, Beijing, China, 7-11 December 1992. International Tropical Timber Organization: Chinese Academy of Forestry, Beijing, China. 96-100.

18. Hisham, N., Othman, S., Rokiah, H., Latif, M., Ani, S., \& Tamizi, M. (2006). Characterization of Bamboo Gigantochloa Scortechinii at different ages. Journal of Tropical Forest Science, 18(4), 236-242.

19. Li, X. (2004). Physical, chemical, and mechanical properties of bamboo and its utilization potential for fiberboard manufacturing. MSc Thesis. Louisiana State University.

20. Wenyue, H., Shiyi, Q., \& \& Youfen, L. (1981). The anatomicalstructure of culms of Phyllostachyspubescens Mazelexh. deLehaie. Bamboo Research, 1: 58-65.

21. Sulaiman, M. S., Wahab, R., Ramle. S. F. M., Mokhtar, N., \& Ghani, R. S. M. (2019). Macroscopic and Microscopic Characteristics of 2- and 4-Year-Old Schizostachyumbrachycladum. Borneo Journal of Sciences and Technology, 1(1): 62-69.

22. Liese, W., \& Grosser, D. (1972). Untersuchungen zur Variabilität der Faserlänge bei bambus. Holzforschung-International Journal of the Biology, Chemistry, Physics and Technology of Wood, 26(6), 202-211.

23. Horn, R. A., \& Setterholm, V. C. (1990). Fiber Morphology and New Crops. In: Janick, J., \& Simon J. E. (eds), Advances in new crops. Timber Press, Portland, Origen. 270-275.

24. Ververis C, Georghiou K, Christodoulakis N, Santas P, Santas R. Fiber dimensions, lignin and cellulose content of various plant materials and their suitability for paper production. Industrial crops and products. 2004 May 1;19(3):245-54.

25. Ireana, Y. (2009). Cell wall architecture, properties and characteristics of bamboo, kenaf and rice straw fibers (Doctoral dissertation, M. Sc Thesis, USM).

26. Viana, L. C., Trugilho, P. F., Hein, P. R. G., Lima, J. T., \& da Silva, J. R. M. (2009). Predicting the morphological characteristics and basic density of Eucalyptus wood using the NIRS technique. Cerne, 15(4), 421-429. 